\title{
Preputial reconstruction after traumatic avulsion in a dog
}

\author{
Reconstrucción prepucial posterior a avulsión traumática en canino \\ RR Huppes ${ }^{\mathrm{a}}$, AG Sprada ${ }^{\mathrm{b}}$, RAR Uscategui ${ }^{\mathrm{c}}$, BLS Passos ${ }^{\mathrm{d}}$, AB De Nardi ${ }^{\mathrm{c}}$, JM Pazzini ${ }^{\mathrm{c}}$, \\ JLC Castro ${ }^{\mathrm{e}}$, BWMinto ${ }^{\mathrm{c}}$, WRR Vicente ${ }^{\mathrm{c}}$ \\ aDepartamento de Medicina Veterinária, Universidade de Uningá, Maringá, PR, Brazil \\ bepartamento de Clínica y Cirugía Veterinaria, Facultad de Ciencias Agrarias y Veterinarias, \\ Universidade Estadual Paulista, Jaboticabal, SP, Brazil. \\ 'Departamento de Clínica y Cirugía Veterinaria, Facultad de Ciencias Agrarias y Veterinarias, \\ Universidade Estadual Paulista, Jaboticabal, SP, Brazil \\ ${ }^{\mathrm{d} C}$ Clínica Veterinária Planeta Bicho, Pato Branco, PR, Brazil \\ eDepartamento de Medicina Veterinária, Pontifícia Universidade Católica do Paraná, Curitiba, PR, Brazil.
}

\section{RESUMEN}

La pérdida amplia del tejido prepucial puede predisponer a lesiones e infecciones del pene y por tanto debe ser tratada con prontitud. Lesiones extensas pueden requerir técnicas reconstructivas y amputación parcial o incluso total del pene. Este reporte describe el caso de un perro mestizo que sufrió una lesión por avulsión traumática en la región inguinal, prepucial y en los miembros pélvicos. El tratamiento quirúrgico fue realizado utilizando un colgajo cutáneo de patrón axial obtenido de la extremidad amputada debido a las severas lesiones que esta presentaba, para realizar la reconstrucción de la región inguinal y del prepucio. La evolución del área afectada fue exitosa, sin la necesidad de realizar una amputación peneana.

Palabras clave: trauma, colgajo, cirugía reconstructiva, amputación.

\section{SUMMARY}

Extensive loss of preputial tissue can cause additional penile injuries and infections, therefore it should be treated promptly. Extensive lesions may require reconstrsuctive techniques and even partial or complete amputation of the penis. This paper report the case of male mongrel dog showing traumatic avulsion lesion in the pelvic limbs, inguinal and preputial region. An axial pattern flap from the limb that was later amputated due to severity of injury was used for the inguinal and preputial reconstruction. The flap technique used was successful in the reconstruction of prepuce without penile amputation and the patient was discharged 14 days later.

Key words: trauma, flap, reconstructive surgery, amputation.

\section{INTRODUCTION}

The prepuce is a retractable tubular skin sheath, attached to the skin of the ventral abdominal wall, containing connective tissue and smooth muscle inside. Its blood supply by penis dorsal artery, cranial and caudal superficial epigastric. The main function of the foreskin is to cover and protect the non-erectile penis. For this, the preputial muscle, which consists of a thin strip of cutaneous muscle of the trunk promotes the expansion of the foreskin over the penis glans preventing the cranial end from being exposed (Christensen 1954).

The preputial disorders can classified as congenital or acquired, the most common congenital disorders are hypospadias, phimosis and paraphimosis, while among the acquired disorders the most frequently reported are related to trauma, infections and neoplasms (Sorribas 2006).

Accepted: 13.08.2015.

* Via de Acesso Prof. Paulo Donato Castellani, s/n, 14884-900 Jaboticabal-SP, Brasil; ramirezuscategui@ hotmail.com
Traumatic preputial injuries that result in considerable tissue loss frequently need surgically treatment. In such cases, reconstructive surgery of the prepuce is indicated, and when not possible, partial or total amputation of the penis may be necessary (Smith and Gourley 1990).

The reconstructive surgery treatment of choice should consider factors such as blood supply, skin viability, wound type and size, as well as considering if function will be restored after reconstruction. Pedicled flaps from the superficial caudal epigastric artery have been described as successful reconstruction technique. The periprepucial skin provides perfusion for the dermis and epidermis through superficial, middle and deep vascular plexus (Smith and Gourley 1990).

Although some reports describe preputial reconstruction surgery techniques, non-surgical treatment guidelines were found in the literature for repairing large lesions in the inguinal and hindlimbs skin. This case study of a dog showing great loss of inguinal tissues which is in need of surgical reconstructive technique using the mixed axial pattern flap technique, aims to describe the use of superficial 


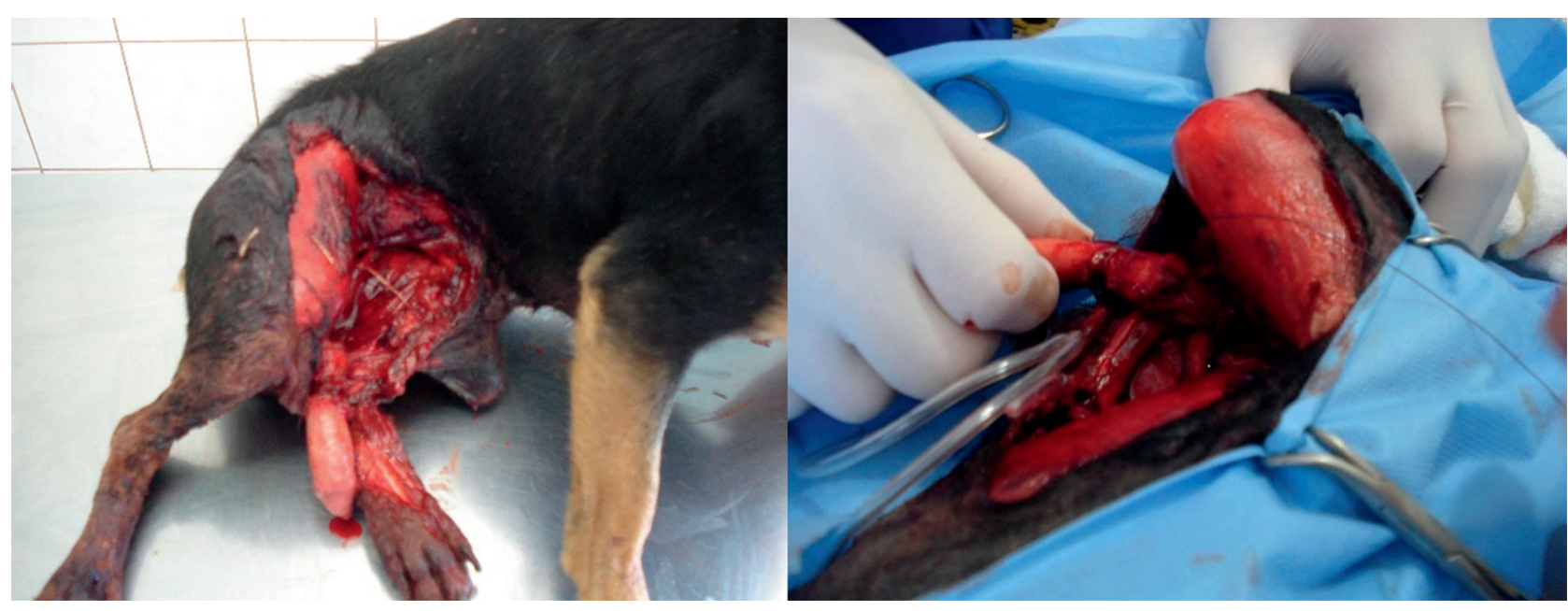

Figure 1. Prepuce and inguinal avulsion, penis exposed and lacerated and tarsal joint mayor trauma. Avulsión prepucial e inguinal, exposición peneana y laceración traumática grave de la articulación del tarso.

iliac and genicular arteries for repair and reconstruction of total avulsion foreskin and inguinal region skin preserving the penile structures.

\section{MATERIAL AND METHODS}

A 5-years-old, male, mongrel dog was admitted at the hospital six hours after hit by a car. The dog had a laceration of the right hind limb, with loss of skin from the external abdominal oblique muscles that advanced caudally to the preputial region until the end of the sartorius muscle (figure 1). The left pelvic limb presented tissues avulsion, musculature exposition, tarsal joint dislocation, metatarsals fracture and exposition of tarsal bone cranial face. The limb was pulseless and showed no signs of deep pain in its extremity. The dog was alert and conscious. Tachycardia and tachypnea were detected in cardiopulmonary auscultation. A ringer lactate fluid therapy $(20 \mathrm{~mL} / \mathrm{kg}$ bolus and $120 \mathrm{~mL} / \mathrm{kg} / 24 \mathrm{~h}$ ) was established immediately to stabilize hemodynamic function of the patient. Urethral rupture in the lower urinary tract was discarded after performing urethral probing. Tramadol hydrochloride ${ }^{1}(4 \mathrm{mg} / \mathrm{kg})$, midazolam $^{2}$ $(2 \mathrm{mg} / \mathrm{kg})$, meloxicam ${ }^{3}(0.1 \mathrm{mg} / \mathrm{kg})$ and cephalexin ${ }^{4}(30 \mathrm{mg} /$ $\mathrm{kg}$ ) were also administered. Subsequently, the wound site was shaved and cleaned with Ringer lactate solution, after removal of the coarse dirt, the left limb, was immobilized using modified Robert Jones bandage until surgery.

The patient was referred to surgery for mechanical removal of devitalized tissues and profuse wound cleaning with ringer lactate pressure irrigation using a $18 \mathrm{G}$ needle.

1 Tramal®, Pfizer laboratories ltda. Guarulhos, SP, Brazil.

2 Midazolam, Eurofarma laboratories ltda. São Paulo, Brazil.

3 Maxicam ${ }^{\circledR}$, Ourofino animal health. Cravinhos, SP, Brazil.

4 Cefalexina, Infabra Ind. Farm. Bras. Ltda. Rio de Janeiro, Brazil.
After neurological examination, absence of deep pain was confirmed and therefore, the amputation of the left pelvic limb was the elected procedure. Due to extensive traumatic avulsion of the prepuce and inguinal skin tissue, the amputation was performed in two stages in order to preserve the pelvic limb skin for the reconstructive surgery. At first, the amputation was make in the tarsal joint due to severe distal trauma, irrigation damage and local contamination.

After surgical debridement of inguinal region, the wound was treated with silver sulfadiazine $(2.5 \%$ twice a day for 20 days) to promote healing by second intention. When the wound was apparently clean and presented granulation tissue (30 days) first intention closed and total hind limb amputation was carried our following literature recommendation. During this procedure, the skin of the limb was kept, taking special care to preserve the pelvic plexus axial surface, genicular artery and the subdermal plexus, for preputial reconstruction (figure 2).

Postoperatively cephalexin (30 mg/kg/BID), meloxicam $(0.1 \mathrm{mg} / \mathrm{kg} / \mathrm{SID})$ and tramadol hydrochloride $(4 \mathrm{mg} / \mathrm{kg} /$ BID) treatment were administer. The animal remained with Elizabethan collar and the wound was clean with saline solution until the stitches were removed. On the fourth postoperative day, there was a dehiscence of the suture on the cranial edge of the prepuce, which treated with $2.5 \%$ silver sulfadiazine healed satisfactorily. The skin stitches were removed on 14 day and the patient was discharge (figure 3). There was a $1 \mathrm{~cm}$ skin adhesion to the penis caudal to the glans, which did not cause problems during micturition. After six months the patient is healthy with no signs of any complications.

\section{RESULTS AND DISCUSSION}

The main diseases of the penis and prepuce in dogs include tumors, infections, trauma and congenital defects 


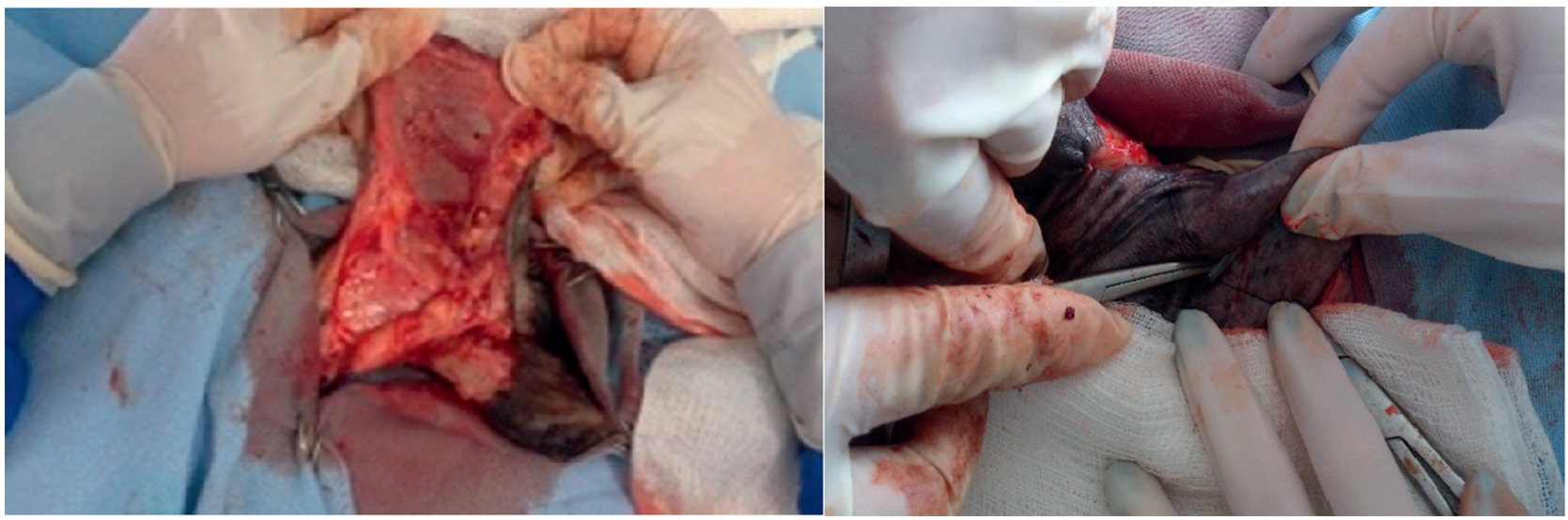

Figure 2. Left limb skin dissection after amputation, skin flap rotation to cover the recipient area and early preputial reconstruction. Disecación de la piel restante posterior a la amputación, rotación del colgajo y recubrimiento temprano del área prepucial.

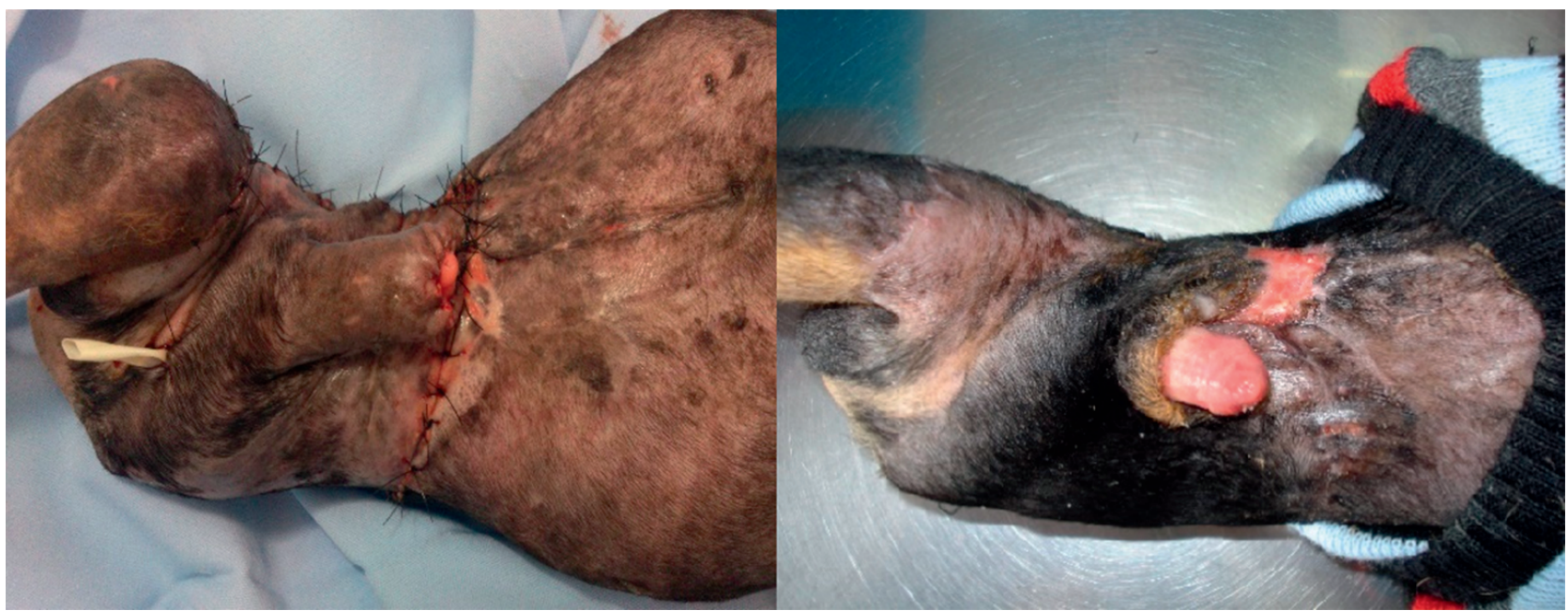

Figure 3. Immediate and $14^{\text {th }}$ day's post-preputial reconstruction appearance.

Apariencia posquirúrgica inmediata y 14 días posterior al procedimiento y alta médica.

such as paraphimosis. The incidence of injury in the prepuce represent approximately $19 \%$ of male reproductive tract lesions. Among the traumatic causes, the most frequently reported are related to the sexual act itself, when owners attempts to separate the animals during coitus. Car accidents and firearms injuries are also frequently observed (Ndiritu 1979). The dog in this report was hit by a car, justifying the wound type and extent presented. Avulsion injuries occur when skin displacement is observed, with or without deep fascia and blood supply injury, depending on intensity of trauma and are often caused by motor vehicle tires (Pavletic 2003).

After initial evaluation, stabilization and pain control, the wound treatment was initiated. The principles described by Pavletic (2003) for wounds management were followed as previously described. It is suggested that after vigorous washing and removal of necrotic tissues, the surgeon should plan timing and method for proper occlusion. To achieve this goal, some factors should be considered such as the degree of contamination, time of evolution, blood supply and the possibility of closure without tension. The extensive tissue loss suffered by patient made impossible the primary wound closure, therefore an open wound treatment was decided. We also suggest that the repair of structures such as tendons, ligaments or bones, when associated with wound, may be postponed until controlled infection and soft tissues viability are guaranteed. In addition, in this case it was decided to postpone amputation of the injured hind limb aiming to use a flap to future preputial reconstruction.

Major traumatic or surgical tissue loss often requires the use of skin grafts and flaps due to primary closure difficulty. Techniques for preputial reconstruction are limited by location. Among the main flap and skin graft donor sites are the caudal epigastric flap that irrigates the breast tissues, and the foreskin to graft of subdermal standard (Smith and Gourley 1990, Hunt et al 2001, Huppes et al 2013).

In this case, both donor sites were affected by a trauma. Since amputation of the left limb was needed and closing of 
the wound was difficult, it was decided to use the limb skin as graft for reconstructive surgery. This alternative donor site was valid under these circumstances. Surgical success was achieved due to great irrigation from genicular axial plexus and good mobility of circumflex iliac artery, which enabled skin graft (Leonatti and Tobias 2004, Hedlund 2007). This surgical maneuver enabled inguinal region covering and prevented penectomy and urethrostomy. These procedures are commonly associated with secondary bacterial infections post-urethrostomy probes when used for more than three days, may also cause fibrosis, cystitis and urethral stricture (Fossum 2005). Fossum (2007) also report urethral ostium stenosis, when the ratio of urethral lumen opening length were six to eight times larger than the urethra incision diameter.

The skin adhesion to the penis could have been avoided with an oral mucosa free graft in the prepuce foramen as described by Smith and Gourley (1990). However, this technique may cause complications such as graft rejection and the need of further surgical intervention, increasing the costs.

Inguinal and preputial regions major tissue losses are difficult to repair, often requiring reconstructive surgery techniques. In this case, the pelvic limb skin flap used showed satisfactory results providing inguinal and preputial region coverage and avoiding penectomy.

\section{ACKNOWLEDGEMENTS}

The authors would like to thank the following funding Agencies of Post Graduation: CNPq, CAPES PEC-PG and FAPESP.

\section{REFERENCES}

Christensen GC. 1954. Angioarchitecture of the canine penis and the process of erection. Am J Anat 95, 227-261.

Fossum TW. 2007. Surgery of the bladder and urethra. In: Fossum TW (ed). Small Animal Surgery. $3^{\text {rd }}$ ed. Elsevier, St. Louis, USA, Pp 663-701.

Hedlund CS. 2007. Surgery of the integumentary system. In: Fossum TW (ed). Small Animal Surgery. $3^{\text {rd }}$ ed. Elsevier, St. Louis, USA, Pp 159-259.

Hunt GB, PL Tisdall, JM Liptak, JA Beck, GR Swinney, R Malik. 2001. Skin-fold advancement flaps for closing large proximal limb and trunk defects in dogs and cats. Vet Surg 30, 440-448.

Huppes RR, AB De Nardi, JM Pazzini, JLC Castro, EL Serafim, FW Souza. 2013. Use of epigastric axial pattern flap to repair defect after resection of squamous cell carcinoma in the abdominal region of a dog-case report. J Bras Cir Vet 2, 230-236.

Leonatti S, KM Tobias. 2004. Skin reconstruction techniques: axial pattern flaps. Vet Med 99, 862-881.

Ndiritu CG. 1979. Lesions of the canine penis and prepuce. Mod Vet Pract 60, 712-715.

Pavletic MM. 2003. The integument. In: Slatter DH (ed). Textbook of Small Animal Surgery. $3^{\text {rd }}$ ed. Saunders, Philadelphia, USA, Pp 250-258.

Smith MM, IM Gourley. 1990. Prepucial reconstruction in a dog. J Am Vet Med Assoc 196, 1493-1496.

Sorribas CE. 2006. Atlas de reprodução canina. Interbook, São Caetano do Sul, Brasil, Pp 185-200. 